\title{
INCIDENCE OF TRICHOMONAS VAGINALIS IN MARITAL PARTNERS*
}

\author{
BY \\ LESLIE WATT AND R. F. JENNISON \\ St. Mary's Hospital for Women, Manchester
}

Vaginitis, due to $T$. vaginalis, continues to cause considerable and often prolonged distress to many women and at the time of writing no really efficacious treatment has been reported. In recent years the relative lack of success in treating the female alone and the high incidence of relapse even after a considerable period of freedom from symptoms has resulted in attention being focused on $T$. vaginalis infestation in the male and the possibility of reinfection during sexual contact.

There have been varying reports as to the incidence of $T$. vaginalis infestation in the male, mostly from venereal disease clinics and therefore representing selected groups comprising mainly men who either had symptoms or had been promiscuous. Lanceley (1953) found that $5 \cdot 8$ per cent. of 310 men with symptoms of non-gonococcal urethritis harboured $T$. vaginalis and Durel, Roiron-Ratner, Siboulet, and Sorel (1954) found an incidence of $12 \cdot 1$ per cent. in 228 similar patients. From Chile, Coutts, VargasSalazar, Silva-Inzunza, Olmedo, Turteltaub, and Saavedra (1955) reported an incidence of 68 per cent. in 2,482 males with non-gonococcal urethritis, but this has yet to be confirmed. All these workers, as well as Feo, Varano, and Fetter (1956), who found $T$. vaginalis in 18 per cent. of 183 men with urethral discharge, used direct methods of examination of stained and unstained specimens to demonstrate the organism. Whittington (1957), using cultural techniques, found $T$. vaginalis in $15 \cdot 3$ per cent. of 326 men with non-gonococcal urethritis and in eight (33.3 per cent.) of 24 symtomless male consorts of women known to have trichomonal vaginitis. This author stresses the superiority of the cultural method of diagnosis over direct examination, as do Kean and Day (1954) and Nicol (1958).

\footnotetext{
* Received for publication May 6, 1960.
}

\section{Present InVestigation}

This study was undertaken in 1957 with the cooperation of the consultant staff of St. Mary's Hospital for Women, Manchester. At the time, the objects were twofold:

(1) To discover the incidence of $T$. vaginalis infestation in the male partners of women suffering from chronic trichomonal vaginitis.

(2) To assess the efficacy of Aminitrazole as an anti-trichomonal agent. This drug was found to be ineffective, as has been reported by various authors (Willcox, 1957; Catterall and Nicol, 1957; Dunlop, Philipp, and Watt, 1958). -

\section{MATERIAL}

The husbands of thirty women who were being treated for chronic trichomonal vaginitis were referred for examination. They represented a highly selected group of white men who had undoubtedly been exposed repeatedly to $T$. vaginalis. A control group of fifty (42 white and 8 coloured) random male patients attending St. Luke's venereal diseases clinic, Manchester, was also studied. This group represented a cross-section of presumably sexually active males. Some had reported because of fear of venereal disease but had no infection, whilst others had been treated for gonorrhoea or nongonococcal urethritis. One patient had been treated for cystitis (Table III, below).

\section{MethoD}

Each male consort was questioned as to previous genito-urinary symptoms, date of last coitus, and the use of condoms. A clinical examination of the lower genitourinary tract, including a two-glass test, was carried out. Specimens for examination were taken from the subpreputial sac if present (only two had been circumcised), the fossa navicularis (Lanceley and McEntegart, 1953), and the prostate after prostatic massage. The first specimen of urine after massage was also collected and centrifuged. 
For the purpose of diagnosis each patient was examined only once, and it is felt that repeat examination might have increased the positive findings. Repeat examinations were made in positive cases who were all asked to re-attend.

The laboratory diagnosis was made by inoculating the specimens obtained into the medium described by Stenton (1957).

The control group were all free from evidence of genito-urinary infection at the time of examination. In this group only prostatic fluid was examined, since it soon became evident from the study group that culture of the prostatic fluid would give the highest incidence of positive results. As with the study group, each patient was examined only once.

\section{RESULTS}

Study Group.-No laboratory evidence of $T$. vaginalis was found in twelve (40 per cent.) of the study group. The average age of these men was 44 years (range 53 to 23). Only two gave a significant previous history, both reporting occasional mild balanitis. The date of the last admitted coitus varied from 3 days to 4 months. No condoms were used by six patients, three always used condoms, one used them occasionally, and in two there was no record. Clinical examination revealed no abnormality in eight patients, but four showed fine threads in the first glass of urine; this is regarded by Lanceley (1953) as suggestive of trichomonal infestation.

Eighteen (60 per cent.) of the study group showed cultural evidence of infestation with $T$. vaginalis (Table I), and all of them were requested to attend for a repeat examination after 2 weeks. Three failed to report. The average age of these men was 37 years (range 57 to 21). One gave a history of urethritis 20 years previously; one was known to have attended a venereal disease clinic on three previous occasions following extra-marital exposure but on each occasion no abnormality was found; one patient had had balanitis for "years". The date of the last admitted coitus varied from 1 day to 5 months. Only two of the eighteen patients used condoms regularly and one of these (Case 4) only for the previous 5 months (Table I).

Eleven (61 per cent.) of the patients with trichomonal infestation showed no clinical abnormality of the lower genito-urinary tract. Three showed fine urinary threads only. Two showed hazy urine with threads. One (Case 12) had no other detectable abnormality. The other (Case 6), who was symtomfree, showed definite evidence of prostatitis with tenderness of the prostate and clumped pus in the prostatic fluid; culture of his urine for organisms other than $T$. vaginalis proved sterile. Two patients showed balanitis: Case 10 had a chronic balanitis with a fibrotic but retractable prepuce and a purulent sub-preputial discharge, and Case 13 had a phimotic non-retractable prepuce. Neither showed glycosuria. Cultures of material from the subpreputial sac were made routinely on the first fifteen patients, but subsequently only on those showing balanitis or phimosis. Positive sub-preputial cultures were found only in the two patients showing clinical balanitis.

TABle I

PATIENTS IN STUDY GROUP SHOWING EVIDENCE OF $T$. VAGINALIS INFECTION

\begin{tabular}{|c|c|c|c|c|c|c|c|c|c|c|c|c|}
\hline \multirow{3}{*}{$\begin{array}{l}\text { Patient } \\
\text { No. }\end{array}$} & \multirow{3}{*}{$\begin{array}{l}\text { Age } \\
\text { (yrs) }\end{array}$} & \multirow{3}{*}{$\begin{array}{c}\text { Last } \\
\text { Coitus }\end{array}$} & \multirow{3}{*}{$\begin{array}{l}\text { Condom } \\
\text { Used }\end{array}$} & \multirow{3}{*}{$\begin{array}{c}\text { Urine } \\
\text { Macroscopic } \\
\text { Appearance }\end{array}$} & \multicolumn{8}{|c|}{ Cultures } \\
\hline & & & & & \multicolumn{4}{|c|}{ Initial Examination } & \multicolumn{4}{|c|}{ Repeat Examination } \\
\hline & & & & & $\begin{array}{c}\text { Sub- } \\
\text { preputial } \\
\text { Sac }\end{array}$ & Urethra & Prostate & Urine & $\begin{array}{c}\text { Sub- } \\
\text { preputial } \\
\text { Sac }\end{array}$ & Urethra & Prostate & Urine \\
\hline $\begin{array}{r}1 \\
2 \\
3 \\
4 \\
5 \\
6 \\
7 \\
8 \\
9 \\
10 \\
11 \\
12 \\
13 \\
14 \\
15 \\
16 \\
17 \\
18\end{array}$ & $\begin{array}{l}24 \\
53 \\
32 \\
36 \\
24 \\
50 \\
37 \\
50 \\
46 \\
57 \\
33 \\
21 \\
24 \\
26 \\
42 \\
43 \\
36 \\
49\end{array}$ & $\begin{array}{l}3 \text { days } \\
2 \text { wks } \\
5 \text { mths } \\
2 \text { mths } \\
1 \text { day } \\
6 \text { wks } \\
2 \text { mths } \\
3 \text { mths } \\
3 \text { wks } \\
4 \text { mths } \\
4 \text { days } \\
3 \text { days } \\
2 \text { days } \\
2 \text { wks } \\
2 \text { days } \\
1 \text { wk } \\
1 \text { wk } \\
6 \text { wks }\end{array}$ & $\begin{array}{l}\text { Yes } \\
\text { No } \\
\text { No } \\
\text { Yes } \\
\text { No } \\
\text { No } \\
\text { No } \\
\text { No } \\
\text { No } \\
\text { No } \\
\text { No } \\
\text { No } \\
\text { No } \\
\text { No } \\
\text { No } \\
\text { No } \\
\text { No } \\
\text { No }\end{array}$ & $\begin{array}{ll}\text { C } & \text { Threads } \\
\text { C } & \\
\text { C } & \text { Threads } \\
\text { C } & \\
\text { C } & \\
\text { H } & \text { Threads } \\
\text { C } & \\
\text { C } & \\
\text { C } & \\
\text { C } & \\
\text { C } & \\
\text { H } & \text { Threads } \\
\text { C } & \\
\text { C } & \\
\text { C } & \text { Threads } \\
\text { C } & \text { The } \\
\text { C } & \end{array}$ & $\begin{array}{l}- \\
= \\
= \\
= \\
= \\
\overline{0} \\
0 \\
+ \\
0 \\
0 \\
+ \\
0 \\
0 \\
0 \\
0 \\
0\end{array}$ & $\begin{array}{l}+ \\
+ \\
+ \\
+ \\
+ \\
+ \\
+ \\
+ \\
+ \\
+ \\
+ \\
+ \\
\pm \\
\pm \\
= \\
= \\
+\end{array}$ & $\begin{array}{l} \pm \\
+ \\
+ \\
+ \\
+ \\
\pm \\
+ \\
+ \\
+ \\
+ \\
+ \\
+ \\
+ \\
+ \\
+ \\
+ \\
+\end{array}$ & $\begin{array}{l}- \\
+ \\
+ \\
+ \\
+ \\
= \\
+ \\
+ \\
+ \\
+ \\
+ \\
\pm \\
+ \\
\pm \\
+\end{array}$ & $\begin{array}{l}= \\
= \\
= \\
= \\
\overline{-} \\
0 \\
0 \\
+ \\
0 \\
0 \\
+ \\
0 \\
0 \\
0 \\
0\end{array}$ & $\begin{array}{l}+ \\
\\
+ \\
+ \\
+ \\
+ \\
+ \\
+ \\
+ \\
+ \\
+ \\
+ \\
+ \\
0 \\
+ \\
+ \\
0 \\
0\end{array}$ & $\begin{array}{l}- \\
\overline{+} \\
+ \\
+ \\
+ \\
+ \\
+ \\
+ \\
+ \\
+ \\
+ \\
+ \\
+ \\
0 \\
+ \\
+ \\
0 \\
0\end{array}$ & $\begin{array}{l}- \\
- \\
+ \\
+ \\
+ \\
= \\
+ \\
+ \\
+ \\
+ \\
+ \\
+ \\
0 \\
+ \\
+ \\
0 \\
0\end{array}$ \\
\hline
\end{tabular}


Table II analyses the results in those cases proved positive. Most consistent results were obtained after culture of prostatic fluid where, on the initial examination, fifteen ( 83 per cent.) of eighteen specimens examined, and on repeat examination, twelve (80 per cent.) of fifteen specimens, were positive. This indicates that a prostatic focus is usually present, and this may be one reason for failure of treatment with local irrigation in the male. In each case an unstained specimen of prostatic fluid was examined. Of the eighteen patients who were found to harbour $T$. vaginalis, thirteen ( 72 per cent.) showed normal prostatic fluid, including eleven (84 per cent.) in which culture of the fluid demonstrated the organism. One patient with clinical prostatitis and positive prostatic culture showed large numbers of clumped pus cells in the prostatic fluid.

TABLE II

ANALYSIS OF RESULTS OF 18 POSITIVE CULTURES

\begin{tabular}{|c|c|c|c|c|c|c|}
\hline \multirow{3}{*}{ Specimen } & \multicolumn{3}{|c|}{ Initial Examination } & \multicolumn{3}{|c|}{ Repeat Examination } \\
\hline & \multirow{2}{*}{$\begin{array}{l}\text { Number } \\
\text { Examined }\end{array}$} & \multicolumn{2}{|c|}{$\begin{array}{l}\text { Culture } \\
\text { Positive }\end{array}$} & \multirow{2}{*}{$\underset{\text { Examined }}{\text { Number }}$} & \multicolumn{2}{|c|}{$\begin{array}{l}\text { Culture } \\
\text { Positive }\end{array}$} \\
\hline & & No. & $\begin{array}{c}\text { Per } \\
\text { cent. }\end{array}$ & & No. & $\begin{array}{l}\text { Per } \\
\text { cent. }\end{array}$ \\
\hline $\begin{array}{lc}\text { Sub-preputial Sac } \\
\text { Urethra } & \ldots \\
\text { Prostate } & \ldots \\
\text { Urine } \quad . & \ldots\end{array}$ & $\begin{array}{l}99 \\
18 \\
18 \\
18\end{array}$ & $\begin{array}{r}2 \\
13 \\
15 \\
10\end{array}$ & $\begin{array}{l}22 \\
72 \\
83 \\
55\end{array}$ & $\begin{array}{r}9 \\
15 \\
15 \\
15\end{array}$ & $\begin{array}{r}2 \\
12 \\
12 \\
9\end{array}$ & $\begin{array}{l}22 \\
80 \\
80 \\
60\end{array}$ \\
\hline
\end{tabular}

Control Group.-Table III shows the results obtained after culturing prostatic fluid from these patients. All had had appropriate treatment and were free from signs and symptoms. Four ( 8 per cent.) of this group of promiscuous males showed evidence of $T$. vaginalis and this compared with 14 per cent. of 378 patients (excluding known contacts of $T$. vaginalis) reported from the Whitechapel Clinic by Whittington (1957). One was white and had been treated for non-gonococcal urethritis, the other three were coloured and had been treated for gonorrhoea and yaws (1), non-gonococcal urethritis (1), and Reiter's syndrome (1). None showed pus cells in the unstained prostatic fluid.

\section{Discussion}

From this study it is evident that a significantly high proportion of males who are repeatedly exposed to $T$. vaginalis during sexual contact themselves harbour the organism (60 per cent. in the study group compared with 8 per cent. in the control). In the control group there were eight coloured men, of whom three ( 37 per cent.) gave positive results, and although the number is small this appears to confirm that infestation with $T$. vaginalis is commoner in the coloured races, whether because of racial susceptibility or greater promiscuity, is unknown.

In the study group only two (11 per cent.) of the eighteen patients who showed cultural evidence of infestation had symptoms (both had balanitis); five (27 per cent.) were symptom-free but showed macroscopic abnormality of the urine, one having definite evidence of prostatitis. This suggests that, in the majority of cases, infestation with $T$. vaginalis in the male is silent and might represent a carrier state.

Catterall and Nicol (1960) reported a series which is the converse of this investigation and have demonstrated $T$. vaginalis in all the female sexual partners of 56 males suffering from $T$. vaginalis urethritis. Both investigations add weight to the growing bulk of evidence that $T$. vaginalis may be transmitted during sexual intercourse. That this is the only method of transmission has yet to be proved and though it may indicate an answer to this question and may help to explain, at least partially, the ineffectiveness of treatment, it does not explain the appearance of symptomatic vaginitis in females who so far as can be ascertained have not been exposed to the possibility of sexual transmission. If one presupposes that $T$. vaginalis is transmitted sexually in every case, one must pre-suppose more promiscuity in more unlikely quarters than would appear to be the case even in the experience of venereologists.

TABLE III

CONTROL GROUP. RESULTS OF CULTURE OF PROSTATIC FLUID, BY RACE

\begin{tabular}{|c|c|c|c|c|c|c|c|c|c|c|}
\hline & & & \multicolumn{5}{|c|}{ Diagnosis } & \multicolumn{3}{|c|}{ Prostatic Culture } \\
\hline \multirow{2}{*}{\multicolumn{3}{|c|}{ Race }} & \multirow{2}{*}{$\begin{array}{c}\text { No } \\
\text { Abnormality }\end{array}$} & \multirow{2}{*}{$\begin{array}{c}\text { Non- } \\
\text { Gonococcal } \\
\text { Urethritis }\end{array}$} & \multirow{2}{*}{ Gonorrhoea } & \multirow{2}{*}{ Cystitis } & \multirow{2}{*}{ Total } & \multirow[b]{2}{*}{$\begin{array}{c}\text { No. } \\
\text { Negative }\end{array}$} & \multicolumn{2}{|c|}{ Positive } \\
\hline & & & & & & & & & No. & Per cent. \\
\hline $\begin{array}{l}\text { White } \\
\text { Coloured }\end{array}$ & $\ldots$ & $\ldots$ & $\begin{array}{r}14 \\
0\end{array}$ & $\begin{array}{r}15 \\
6\end{array}$ & $\begin{array}{r}12 \\
2\end{array}$ & $\begin{array}{l}1 \\
0\end{array}$ & $\begin{array}{r}42 \\
8\end{array}$ & $\begin{array}{r}41 \\
5\end{array}$ & $\frac{1}{3}$ & $\begin{array}{r}2 \cdot 4 \\
37 \cdot 5\end{array}$ \\
\hline Total & $\ldots$ & $\ldots$ & 14 & 21 & 14 & 1 & 50 & 46 & 4 & 8 \\
\hline
\end{tabular}


Because, however, of the high incidence of $T$. vaginalis in sexual partners, it would seem that in order to preclude the possibility of re-infection any treatment which is necessary should be given to both partners simultaneously.

One side-issue of the study was the attitude of the male partners to investigation. In spite of the fact that the examinations were carried out in a hospital for diseases of women and were not in any way connected with a venereal disease clinic, practically every patient queried the possibility of venereal disease and in spite of repeated reassurance and explanation some still harboured lingering doubts. In the lay mind, especially in the less well-educated groups, it is difficult to separate venereal disease (i.e. syphilis and gonorrhoea) from genital infections of other kinds. Venereal disease suggests infidelity and no wife will relish the thought of an unfaithful husband. Equally, the thought that he may be a cuckold may arouse anxiety, anger, or even aggression in a husband. It would seem unwise, therefore, to carry out any combined treatment, at least in the present state of our knowledge, in venereal disease clinics with their diminishing, but none the less real, social stigma. The venereologist, both by training and experience, is best fitted to examine males for evidence of $T$. vaginalis, but such examinations should be carried out far from his venereal diseases clinic. The majority of $T$. vaginalis infestations comes to light in the gynaecological department and ideally investigation of the sexual partners should be conducted at special sessions in that department.

\section{Summary}

The husbands of thirty women suffering from trichomonal vaginitis were examined. Twelve ( 40 per cent.) showed no evidence of infection, but eighteen (60 per cent.) showed $T$. vaginalis in cultures of specimens obtained from the lower genito-urinary tract.

In a control group of fifty male patients attending a venereal diseases clinic, four (8 per cent.) showed evidence of infestation with $T$. vaginalis.

Culture of the prostatic fluid gave the highest proportion ( 83 per cent.) of positive results in men who were infected. This indicates a possible prostatic focus in most cases.

The evidence supports the contention that $T$. vaginalis may be transmitted sexually.

Care in the investigation of such maritial cases in venereal diseases clinics is advocated.

We wish to express our thanks to Mr. P. Stenton, F.I.M.L.T., and Mr. E. F. F. Howlett, S.R.N., for their assistance.

\section{REFERENCES}

Catterall, R. D., and Nicol, C. S. (1957). Brit. med. J., 2, 29. - (1960). Ibid., 1, 1177.

Coutts, W. E., Vargas-Salazar, R., Silva-Inzunza, E., Olmedo, R. Turteltaub, R., and Saavedra, J. (1955). Ibid., 2, 885.

Dunlop, E. M. C., Philipp, E., and Watt, J. D. (1958). Brit. J. vener. Dis., 34, 57.

Durel, P., Roiron-Ratner, V., Siboulet, A., and Sorel, C. (1954). Ibid., 30, 69.

Feo, L. G., Varano, N. R., and Fetter, T. (1956). Ibid., 32, 233.

Kean, B. H., and Day, E. (1954). Amer. J. Obstet. Gynec., 68, 1510

Lanceley, F. (1953). Brit. J. vener. Dis., 29, 213.

and McEntegart, M. G. (1953). Lancet, 1, 668.

Nicol, C. S. (1958). Brit. J. vener. Dis., 34, 192.

Stenton, P. (1957). J. med. Lab. Technol., 14, 228.

Whittington, M. J. (1957). Brit. J. vener. Dis., 33, 80.

Willcox, R. R. (1957). Ibid., 33, 115.

Fréquence du trichomonas vaginalis chez des partenaires maritaux.

\section{Résumé}

On examina les époux de trente femmes atteintes de vaginite à trichomonas. Douze d'entre eux $(40 \%)$ n'accusèrent pas de signes d'infection, mais chez les autres dix-huit $(60 \%)$ on trouva le $T$. vaginalis dans les cultures des prélèvements des voies génito-urinaires inférieures.

Dans le groupe témoin de $\mathbf{5 0}$ malades fréquentant un dispensaire antivénérien, quatre d'entre eux $(8 \%)$ révélèrent des signes d'infestation par le $T$. vaginalis.

Des cultures du liquide prostatique donnèrent la plus forte proportion $(83 \%)$ des résultats positifs chez des hommes infectés. Cela indique un foyer prostatique probable dans la plupart des cas.

Ces données viennent à l'appui de la théorie que le $T$. vaginalis peut être transmis par voie sexuelle.

On préconise des soins particuliers quand on recherche des cas maritaux dans les dispensaires antivénériens. 